\title{
Optimal Operation of Multi-Converter-UPQC for Power Quality Improvement in Distribution
}

\author{
N.P. Gopinath, M. Mugunthan, J. Silambarasan
}

\begin{abstract}
In this paper the power compensation for power system during faults in distribution line is described. The proposed system is designed by using the series and shunt APF based hysteresis control scheme to compensate harmonic distortion and control the system stability. Moreover, the system can be compensated the current as well as voltage simultaneously by using Unified Power Quality Controller (UPQC). Voltage Source Inverters (VSI) are connected in both the series and shunt. The main feeder is used to injecting power to these inverters using transformer and VSI compensate the imperfection line such as sag, interruption, swell, voltage unbalance. DC link voltage of the system is maintained at series and shunt operation. The proposed system is verified successfully and tested using MATLAB/Simulink.
\end{abstract}

Keywords: APF, Multi-Converter, Power Quality, UPQC, VSI.

\section{INTRODUCTION}

$\mathrm{T}_{\mathrm{h}}$ he electricity demand is increasing with today world. Power quality improvements are essential factor in power system and the power quality issues can be voltage below the nominal value (sag), the voltage above nominal value (swell), unbalanced voltage [1]. The enhancement of nonlinear load affects the power system and caused to power quality diminution. In power system and electricity grids the quality of power problems occurred like sag, distortion, harmonics in supply power as well as load energy. Photo -Voltaic (PV) and Fuel cell are sources to maintain dc link voltage and the quality problems in power can be reduced [2]. In the steel industries the non linear loads i.e especially furnaces are decreasing the power quality such as harmonics, fluctuations in power and power loss that also affect the other loads. To control the harmonics the UPQC is used in this furnace application in steel industries [3]. The UPQC is to improve the quality of power and its way along with sending and receiving ends voltage. In this the receiving end voltage is regulated using the feedback controllers certainly. The controller's performance are compared and verified that are fuzzy logic controller, proportional controller, and proportional resonant [4]. In power electronics distribution area and industries are suffered by problems in quality of power according to their devices. To mitigate those issues in system the active filter power conditioning equipment and interfaced in series and parallel [5]. In the Static compensator

Revised Manuscript Received on December 30, 2019.

N.P. Gopinath*, Assistant Professor, Department of Electrical \& Electronics Engineering, Chennai, India.

Mugunthan M, Silambarasan J, Department of Electrical \& Electronics Engineering, AarupadaiVeedu Institute of Technology, Chennai, India.
(STATCOM) with multilevel inverter (MLI) is used for bus voltage improvement and the reactive power. In the improvement of low voltage and disturbances in energy, the power based device dynamic voltage restorer (DVR) [6]. The voltage improvement of DVR and distributed STATCOM (DSTATCOM) are compared with the results [7]. In micro grids, the model predictive controller is used to enrichment of the power quality using D-STATCOM as well as UPQC [8]. The particle swarm optimization (PSO) is achieved to power compensation using model predictive controller to distributed generators. The harmonic reduction in system is done by using PSO and Kalman filter [9-10]. The converters and model predictive controller are used to UPQC for energy compensation. 3 phases UPQC the Control strategy of pulse width modulation (PWM) with fuzzy sliding mode is used. This control is achieved in terms of load unbalance, harmonics in current, and distortion voltage. The three phase locked loop is used with the series filter to control the issues power quality that in load and source side. The distortions in the current and voltage have an effect on industrial and household appliances. In [11] FLC controller based UPQC is achieving diminution in power quality issues.

The design of MC-UPQC based topology for compensating the voltage that falls below a nominal voltage or supply voltage that means sag is presented in this paper. The APF based hysteresis controller (HC) is utilized for both series and shunt integrations control. APF based HC is designed for series as well as shunt converter for providing the control signals to the both converters (which are connected in series and shunt). Series LC filter and shunt LC filter for each converter in the system respectively as the configuration of back to back conversion system. The series connection of VSI converter is interfaced with the converter in shunt connection due to the merits of power factor correction (PFC) as well as the reduction in the DC link voltage requirement. Also the capacitor voltage stress can be reduced in the way of using split range of capacitor. The system is verified in MATLAB/Simulink.

\section{PROPOSED SYSTEM}

This paper proposed the APF based hysteresis controller of MC-UPQC the quality improvement in power for the high transmission and distribution systems. Under the fault condition and issues which are occurring at power systems, the MC-UPQC system is analyzed. For the purpose of system control, the APF combination of both shunt and series are used. 
In this system the regulation of current profile is done by using the shunt connected converter where as the voltage regulated by series converter. At the non linear load, the compensating converters are controlled by APF with HC. The resulting control signals are injected for the system performance and steady state supply. sector, industries and power generation units having the essential power quality issue. The mainly common problems occur in the power system like, Harmonics, Voltage variations, Brownouts, Interruptions Swells, Spikes, as voltage sags. The Power disturbances can harms the system operation and leads to the inability to meet the load demand. The issues are additional power factor, unbalanced voltage and current, sag, flickers, swell etc. But the factors that considered for these issues are such as improper wiring connection with the grounding, the presented harmonics in parameters and the overloaded circuits.

\section{A. Basic Configuration of UPQC}

The system of MC-UPQC comprises the two series converter integration with APF where the dc link capacitor is interfaced between them; shunt converter with APF filter for the establishment of system steady state. This method can enhances the power factor and also propagation of the harmonics in load current can be prevented. The Schematic design of MC-UPQC arrangement is shown in fig.1.

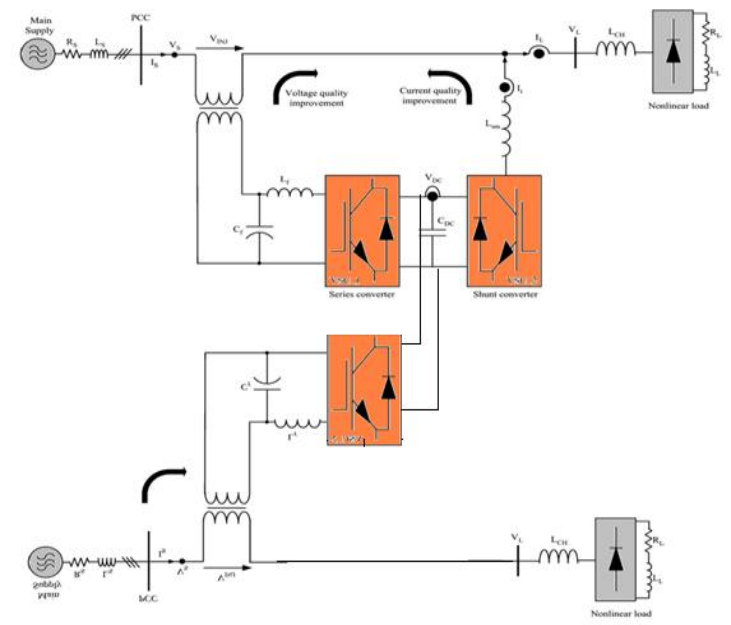

Fig. 1. Schematic configuration of MC-UPQC

\section{B. Control Method}

An efficient Active Power Filter is evaluating and controls the power quality problems and harmonics distortion. The quality of APF depends on three concerns are follows Power circuit configuration, method used to extract the harmonic content, The modulation and control method used to implement the compensation scheme.

A control algorithm for a three-phase filter represent by a series active power filter (SAPF) is proposed and it is represent in fig.2. The control target used provides high impedance for the harmonics while providing zero impedance for the fundamental. This strategy is achieved when the APF generates a voltage proportional to the source current harmonics. The main purpose of these converters can compensate the voltage disturbance in series at main supply or
The major levels of electrical energy users like the service

source side because of distribution line fault. It reduces the requirement of DC sources. These converters are working as a controlled rectifier and from the main source the rectifier is powered. Similarly, during the supply injection, it can work as inverter from dc link to main supply.

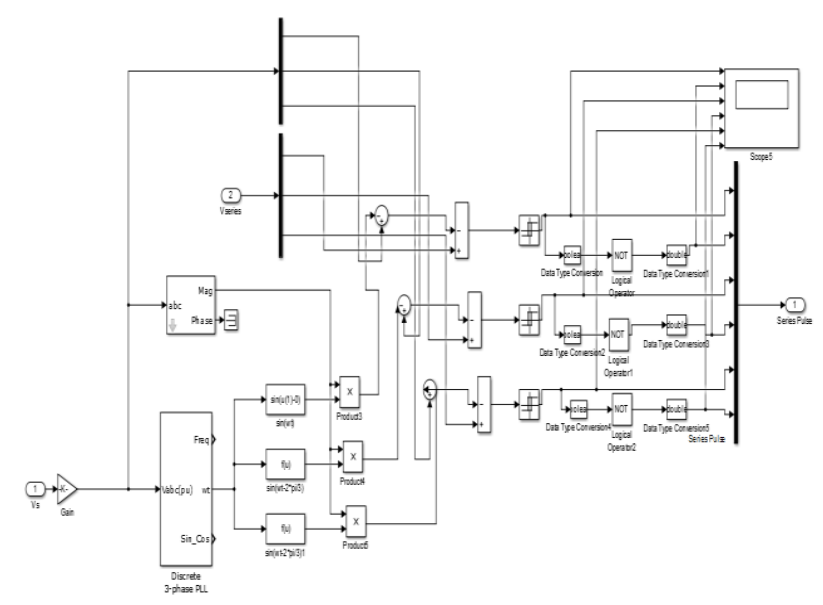

Fig. 2. Series APF based HC

In the distribution line an analysis of the shunt injection type active filter is located and it is shown in fig.3. Function of the shunt converter is to compensate the current related issues in the system. Transformation of $\mathrm{ABC}$ to $\mathrm{dq} 0$ is done and the final transformation is again converted into $\mathrm{ABC}$ signal. The generated signal $\mathrm{ABC}$ is set point which is fed to PWM of hysteresis control band. Finally, the control signals for the shunt converter regulation are generated.

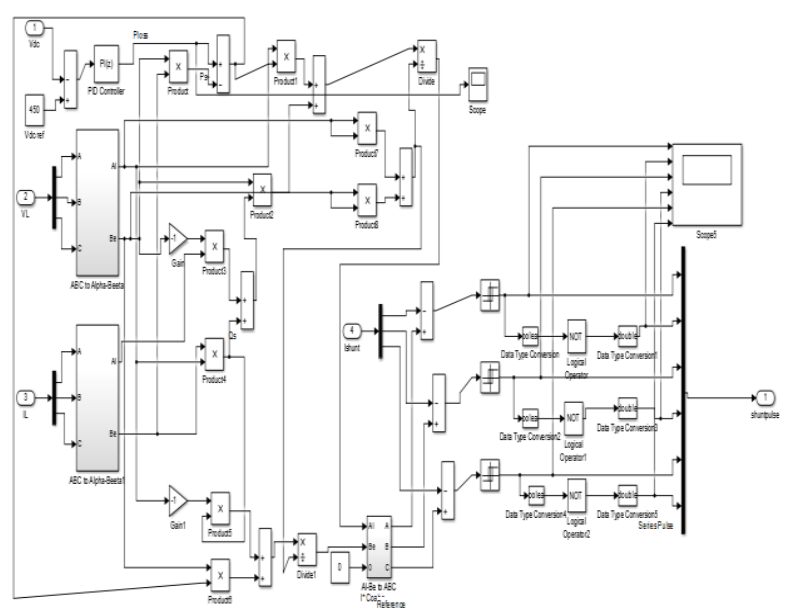

Fig. 3. Shunt APF based hysteresis controller

\section{RESULT AND DISCUSSION}

The detailed three phase MC-UPQC topology model of APF filter with $\mathrm{HC}$ is explained briefly. By means of achieving the power compensation, the power generation stability and the $\mathrm{HC}$ controller used to provide the control signals to system for the power quality improvement. The results and compensated parameters are evaluated using MATLAB/Simulink. 
To control the converters which are connected in series, and shunt the HC controller is used with a APF filter for the desired current production to compensate the system line. In series compensation, it consists of two series converter to compensate the voltage at both distribution lines.

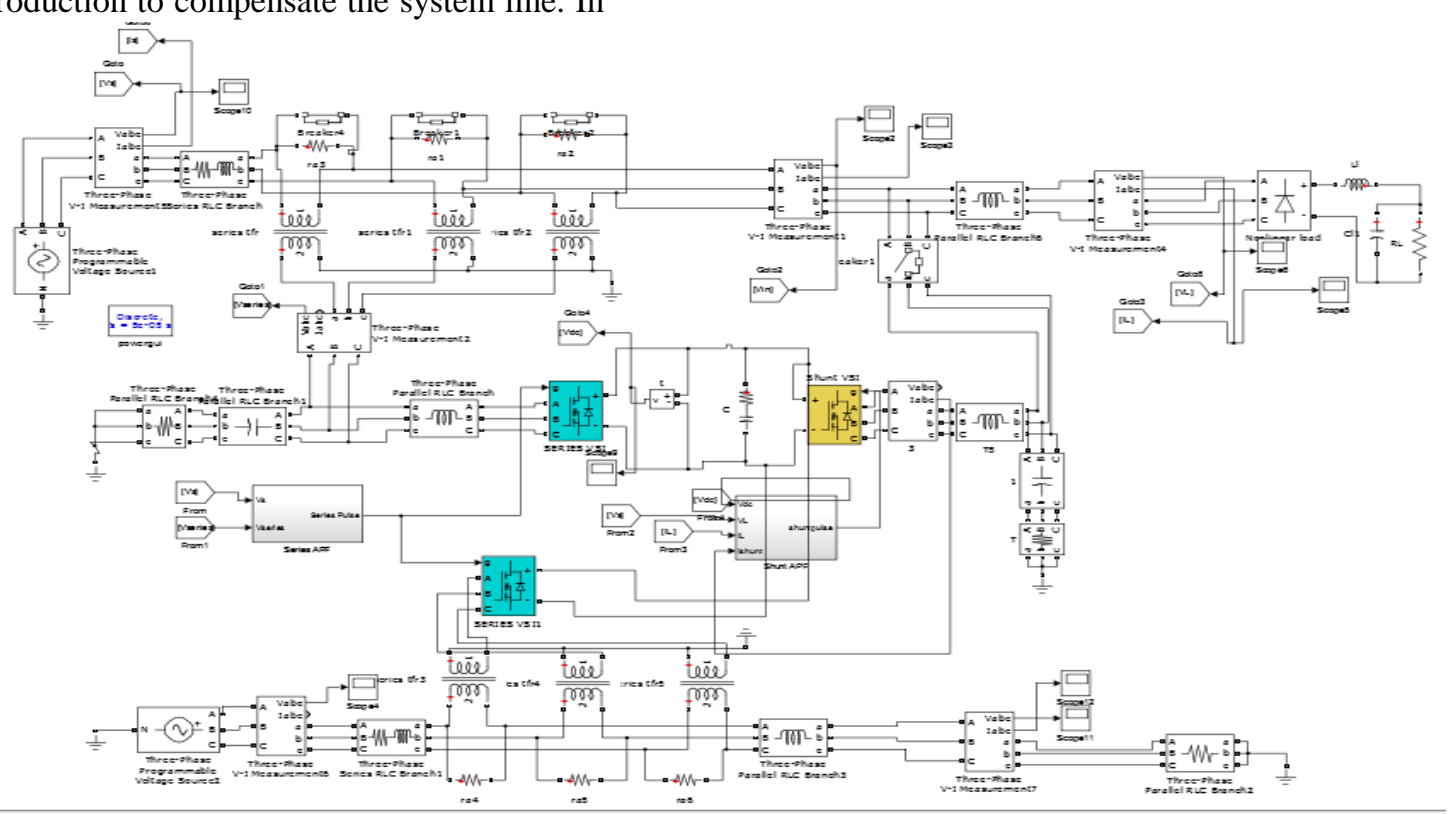

Fig. 4. Simulink representation of the proposed MC-UPQC

Fig.5. shows the input waveform of sag voltage and current. The voltage and current values are $380 \mathrm{~V}$, and 40amps. Input voltage is drop below $300 \mathrm{~V}$, and current is swell up to 50amps. Fig.6. \&7 shows the injected voltage and current waveform of the proposed system. Fig. 8 shows the compensated output voltage and current waveform of linear and non-linear load condition.
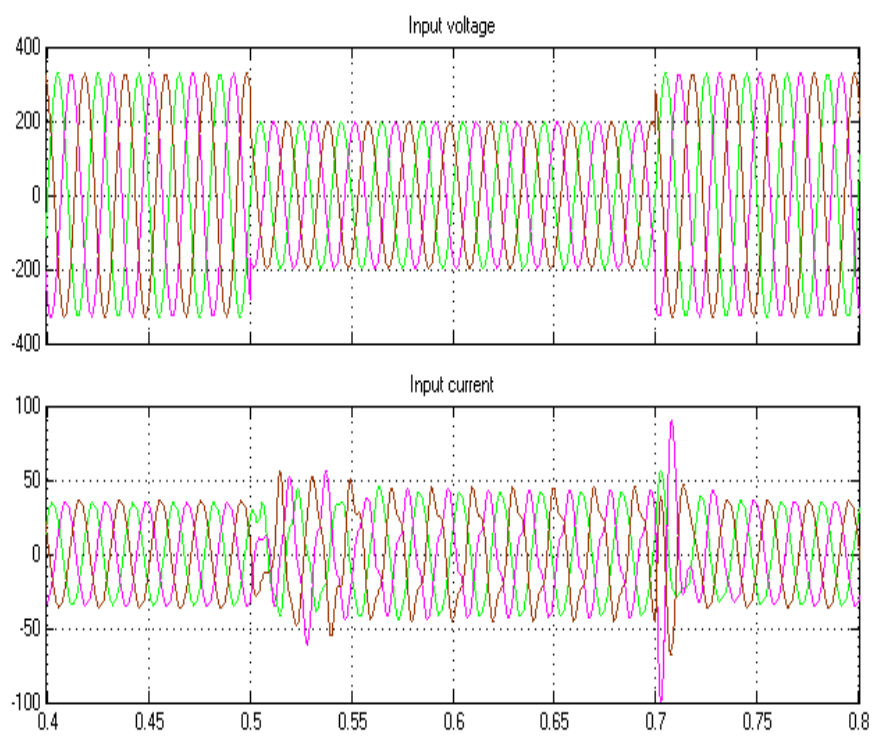

Fig. 5. Faulty input voltage and current

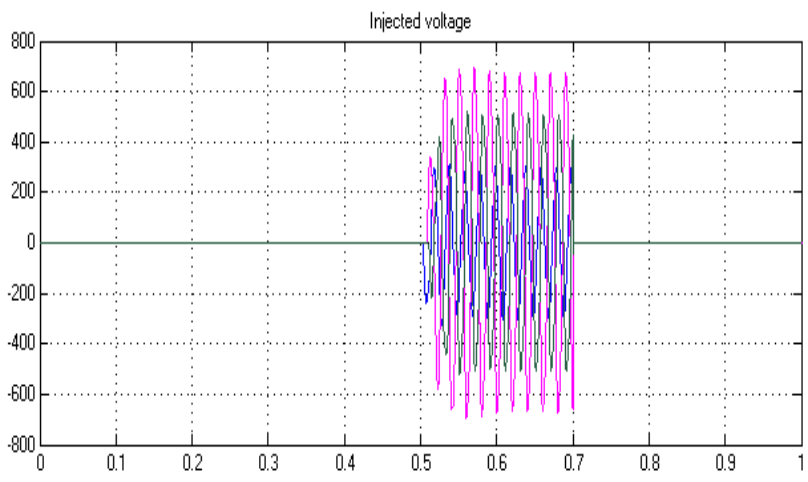

Fig. 6. Injected voltage

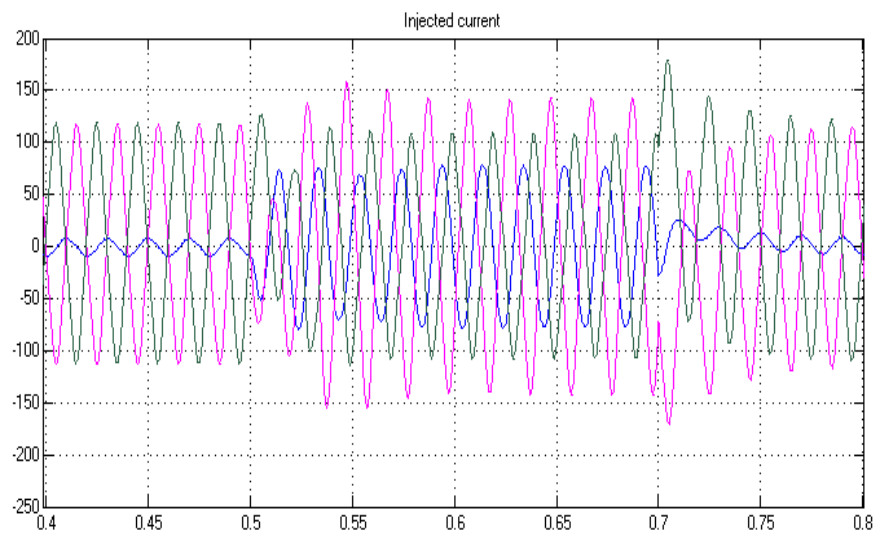

Fig. 7. Injected current 


\section{Optimal Operation of Multi-Converter-UPQC for Power Quality Improvement in Distribution}
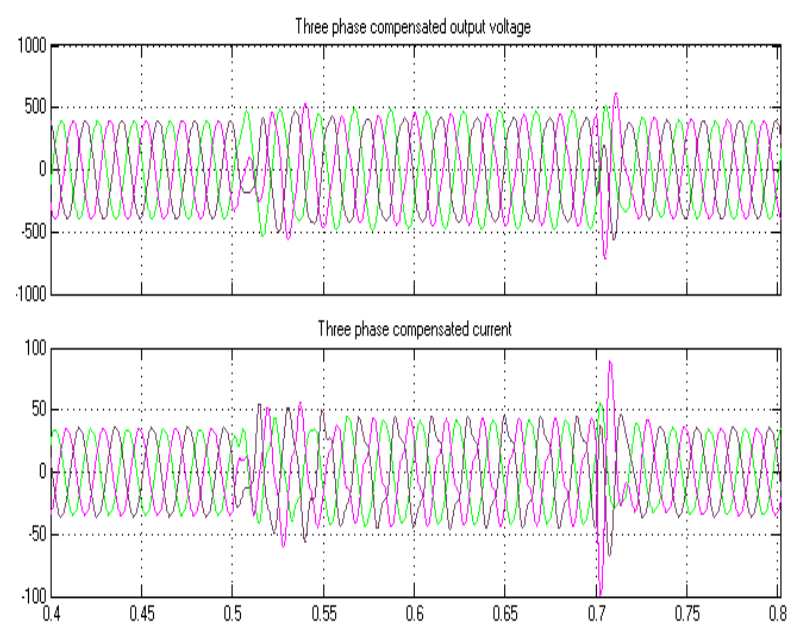

Fig. 8. Compensated output voltage and current

\section{CONCLUSION}

A design of 3 phases MC-UPQC system is planned with the system control method of APF based hysteresis controller. This system is controlled in various ability of compensating signal provision for both shunt and series converters during faults and issues. The control strategy presented in this paper leads to efficient system compensation when compared with existing method of control and the performance of the system is analyzed and investigated. The compensation of power is achieved easily in the various conditions with the balanced supply as well as sinusoidal signals for the three phase system. Here the error reduction is achieved using the control method of APF with hysteresis controller and the compensation efficiency is improved by $\mathrm{HC}$.

\section{REFERENCES}

1. A.K. Panda, N. Patnaik, "Management of reactive power sharing \& power quality improvement with SRF-PAC based UPQC under unbalanced source voltage condition," International Journal of Electrical Power \& Energy Systems. 2017, nol. 84, pp. 182-94.

2. S. Samal, P.K. Hota, "Power Quality Improvement by Solar Photo-voltaic/Fuel Cell Integrated System Using Unified Power Quality Conditioner," International Journal of Renewable Energy Research, vol. 7, no. 4, 2017, pp.2075-2084.

3. S. Samal, P.K. Hota, "Power Quality Improvement by Solar Photo-voltaic/Wind Energy Integrated System Using Unified Power Quality Conditioner," International Journal of Power Electronics and Drive Systems, vol. 8, No. 3:1424, 2017.

4. G.P. Anjaneyulu, D.P. Raju, "Fuzzy Logic Controlled Interleaved Boost Converter Fed Unified Power Quality Conditioner System," International Journal of Electrical Engineering \& Technology. 2017, vol. 8 , no. 3 .

5. S.S. Jadhao, G.P. Ratnaparkhi, G.M. Dhole, S.R. Paraskar, "Voltage quality enhancement using unified power quality conditioner (UPQC)," In2017 International Conference on Energy, Communication, Data Analytics and Soft Computing, 2017, pp. 3270-3274.

6. G. Ramya, V. Ganapathy, P. Suresh, "Power quality improvement using multi-level inverter based DVR and DSTATCOM using neuro-fuzzy controller,"International Journal of Power Electronics and Drive Systems, vol. 8, no. 1:316, 2017.

7. Priyanga Shalni, Keerthivasan M, Suresh Padmanabhan, "Voltage Sag Compensation Using Distribution Static Compensator (DSTATCOM)," International Journal of Advances in Signal and Image Sciences, vol.1, no.1,2015,pp.19-28

8. O.P. Taiwo, R. Tiako, I.E. Davidson, “Application of dynamic voltage restorer for power quality improvement in low voltage electrical power distribution network: An overview," In International Journal of Engineering Research in Africa, Vol. 28, pp. 142-156, 2017.
9. A.C. Prajith Prabhakar, "Predictive Based DSTATCOM and UPQC for Power Quality Advancement in Microgrids".

10. J. Kotturu, S. Kothuru, P. Agarwal, "Simplified Predictive Control of Unified Power Quality Conditioner," In2018 9th IEEE International Symposium on Power Electronics for Distributed Generation Systems (PEDG) 2018, pp. 1-6.

11. S. Ivanov, M.Ciontu, D. Sacerdotianu, A. Radu, "Simple control strategies of the active filters within a unified power quality conditioner (UPQC)," In2017 International Conference on Modern Power Systems (MPS), 2017, pp. 1-4.

\section{AUTHORS PROFILE}

N.P. Gopinath Assistant Professor Department of

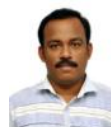
Electrical \& Electronics Engineering, Vinayaka Missions Research Foundation, Chennai, India.

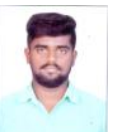

Mugunthan M UG Student, Department of Electrical \& Electronics Engineering, AarupadaiVeedu Institute of Technology, Chennai, India.

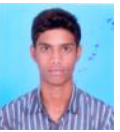

Silambarasan J UG Student, Department of Electrical \& Electronics Engineering, AarupadaiVeedu Institute of Technology, Chennai, India. 